\title{
Perbandingan Efek Musik Klasik Mozart dan Musik Tradisional Gamelan Jawa terhadap Pengurangan Nyeri Persalinan Kala I Fase Aktif pada Nulipara
}

\author{
Nike Sari Oktavia, ${ }^{1}$ Supriadi Gandamiharja, ${ }^{2}$ Ieva B. Akbar ${ }^{3}$ \\ ${ }^{1}$ Program Magister Kebidanan Politeknik Kesehatan Padang, ${ }^{2}$ Bagian Onkologi, ${ }^{3}$ Departemen Faal \\ Fakultas Kedokteran Universitas Padjadjaran
}

\begin{abstract}
Abstrak
Rasa nyeri persalinan yang kadang luar biasa pada sebagian wanita muncul akibat refleks fisik dan respons psikis ibu. Musik terbukti dapat meningkatkan konsentrasi, mengurangi kecemasan, dan mengalihkan perhatian rasa nyeri yang dialami pasien. Tujuan penelitian ini untuk mengetahui apakah musik klasik Mozart dan tradisional gamelan jawa dapat mengurangi nyeri persalinan, dan apakah musik klasik Mozart lebih baik daripada tradisional gamelan jawa terhadap pengurangan nyeri persalinan kala I fase aktif pada nulipara. Penelitian ini menggunakan metode eksperimen semu dengan total 30 orang nulipara yang berada dalam kala I fase aktif persalinan. Penelitian dilakukan di RSIA Arvita Bunda Kabupaten Sleman Yogyakarta selama Desember 2010-Maret 2011. Subjek penelitian berada dalam 3 kelompok: Mozart $(n=10)$, gamelan jawa $(n=10)$, dan kontrol $(n=10)$. Penilaian nyeri dilakukan dua kali pada masing-masing kelompok dengan numerical rating scale (NRS), yaitu saat ibu berada di awal fase aktif dan di akhir kala I persalinan. Uji analisis statistik menggunakan Wilcoxon Signed Ranks (Z) dan Uji Mann Whitney. Hasil yang didapatkan antara lain, pada kelompok Mozart terdapat nilai median 7,5 (710) menjadi 6 (5-9), pada kelompok gamelan jawa median 7 (5-9) menjadi 7,5 (5-10), sementara pada kontrol median 7 (4-9) menjadi 9,5 (6-10). Terdapat perbedaan nyeri antara kelompok Mozart dan kontrol $(\mathrm{p}=0,001)$, terdapat perbedaan nyeri antara kelompok gamelan jawa dan kontrol $(\mathrm{p}=0,022)$, dan perbandingan antara musik klasik Mozart dan musik tradisional gamelan jawa $(\mathrm{p}=0,124)$. Kesimpulan penelitian ini, musik klasik Mozart dan tradisional gamelan jawa mengurangi nyeri persalinan kala I fase aktif pada nulipara, serta tidak ada perbedaan antara keduanya. [MKB. 2013;45(4):218-25]
\end{abstract}

Kata kunci: Musik klasik Mozart, musik tradisional gamelan jawa, nyeri persalinan

\section{Comparison of Classical Music Mozart Efect and Javanese Gamelan Music Efect to Relief Labor Pain in Stage I Active Phase for Nullipara}

\begin{abstract}
Labor pain that may sometimes extreme in some pregnant women arises because of the physical reflection and psychological response of the mother. Music is proven to increase concentration, create comfort, and distract the feeling of pain in patients. The aim of this study was to explore wether Mozart classical music and Javanese gamelan music can decrease the level of pain in the process of labor and whether Mozart is better than gamelan in reducing pain in nulipara during stage 1 active phase of labor. This study was conducted by using quasy experiment method with a total of 30 nullipara patients in stage 1 active phase in RSIA Arvita Bunda, Sleman Yogyakarta during the period of December 2010 to March 2011. The subjects were divided into three groups: Mozart $(n=10)$, Javanese gamelan $(n=10)$, and control $(n=10)$. Pain assesment were conducted twice for each group using the numerical rating scale (NRS), which was performed during the beginning of stage I active phase of labor and the end of stage 1 active phase of labor. The data were analyzed using Wilcoxon Signed Ranks ( $Z$ ) and Mann Whitney statistical tests. The results of this study showed a change in the median value from 7.5 with a range of 7-10 to median 6 (5-9) in Mozar group, from the median value of 7 (5-9) to 7.5 (5-10) in gamelan group and from median 7 (4-9) to 9.5 (6-10) in control group. There was a significant difference between Mozart and control groups ( $\mathrm{p}=0.001)$, and between Javanese gamelan group and control group $(\mathrm{p}=0.022)$, and the comparison between Mozart classical music and Javanese gamelan music $(\mathrm{p}=0.124)$. It is concluded that Mozart classical music and Javanese gamelan relief pain in stage 1 active phase of nullipara and no differences are found between the two. [MKB. 2013;45(4):218-25]
\end{abstract}

Key words: Javanese gamelan music, labor pain, Mozart classical music

Korespondensi: Nike Sari Oktavia, Jl Gajah Mada Komplek Kesehatan Gunung Pangilun, mobile 081363492515, email ikesay@gmail.com 


\section{Pendahuluan}

Persalinan merupakan peristiwa fisiologis yang dalam prosesnya menimbulkan rasa nyeri hebat, bahkan sebagian wanita mengalami nyeri yang luar biasa. Rasa nyeri muncul akibat refleks fisik dan respons psikis ibu. Ketegangan emosi akibat rasa cemas sampai rasa takut dapat memperberat persepsi nyeri selama persalinan. Nyeri yang dialami ibu ketika menghadapi proses persalinan dapat merangsang ketakutan, sehingga timbul kecemasan yang berakhir dengan kepanikan. Hal ini dapat menimbulkan respons fisiologis yang berpotensi mengurangi kemampuan rahim untuk berkontraksi, dengan akibat akan memperpanjang waktu persalinan. ${ }^{1-3}$ Nyeri pada kala I merupakan nyeri yang berat dengan waktu yang lebih lama, untuk itu perlu diperhatikan penanganan untuk mengatasi nyeri pada kala I persalinan. ${ }^{4}$

Dalam sebuah studi di Vesoul HospitalPerancis, para peneliti melaporkan bahwa ibu hamil yang ikut serta dalam "pelatihan Tomatis" (pelatihan mendengarkan musik yang diambil dari nama seorang dokter yang juga seorang terapis musik) selama empat minggu ketika usia kehamilan delapan bulan akan makin pendek waktu rawat inap di RS (rumah sakit) dan semakin berkurang kejadian komplikasinya. Kelompok pertama yang dipersiapkan secara konvensional membutuhkan waktu persalinan rata-rata selama 3 jam 30 menit, kelompok kedua tanpa persiapan membutuhkan 4 jam, dan kelompok Tomatis itu hanya 2 jam 30 menit. Pembedahan Caesar hanya diperlukan pada 4\% kelompok Tomatis, 13\% pada kelompok yang dipersiapkan, dan $15 \%$ pada kelompok yang tidak dipersiapkan. Sebanyak $60 \%$ pasien Tomatis tidak membutuhkan obat penghilang nyeri dibandingkan dengan 46\% kelompok yang dipersiapkan secara konvensional dan 50\% dari kelompok ibu yang tidak mendapat persiapan. Para ibu yang menggunakan metode Tomatis juga mengungkapkan berkurangnya kecemasan tentang melahirkan. ${ }^{5}$ Penelitian Tomatis melihat efek musik secara tidak langsung karena musik didengarkan saat ibu hamil delapan bulan. Musik adalah bentuk seni yang paling halus, namun berpengaruh besar pada pusat fisik dan jaringan saraf. Musik juga memengaruhi sistem saraf parasimpatis atau sistem saraf automatis, baik secara langsung maupun tidak langsung. ${ }^{6}$ Musik klasik Mozart telah teruji sebagai terapi yang aman dan efektif, demikian juga dengan musik tradisional gamelan jawa yang memiliki irama teratur dan menenangkan dengan ketukan 60-90 per menit mirip dengan musik klasik Mozart. ${ }^{5,7-9}$

Tujuan penelitian ini adalah untuk mengetahui apakah terdapat pengurangan rasa nyeri persalinan kala I fase aktif pada nulipara yang mendengarkan musik klasik Mozart, mengetahui apakah terdapat pengurangan rasa nyeri persalinan kala I fase aktif pada nulipara yang mendengarkan musik tradisional gamelan jawa, dan mengetahui apakah mendengarkan musik klasik Mozart lebih baik dibandingkan dengan musik tradisional gamelan jawa dalam mengurangi nyeri persalinan kala I fase aktif pada nulipara.

\section{Metode}

Penelitian ini untuk melihat efek musik terhadap pengurangan nyeri persalinan secara langsung, berbeda dengan penelitian yang dilakukan oleh Tomatis. Berdasarkan hal tersebut penelitian ini menggunakan sampel ibu yang akan bersalin. Metode yang dipergunakan adalah eksperimental semu (quasi experimental research) dengan mengambil sampel secara consecutive sampling. Subjek penelitian berjumlah 30 orang dengan rincian 10 orang per kelompok yang datang bersalin ke RSIA Arvita Bunda Kabupaten Sleman, Yogyakarta dari Desember 2010 sampai dengan Maret 2011 dengan kriteria inklusi: nulipara dalam kala I fase aktif dengan pembukaan serviks 4-9 cm, hamil normal, dapat membaca dan menulis, serta dapat berkomunikasi dengan baik. Semua pasien yang memenuhi kriteria inklusi dan bersedia menjadi responden dikelompokkan sesuai dengan isi amplop yang diterimanya yang terdiri atas tiga kelompok. Kelompok pertama mendapatkan perlakuan diperdengarkan musik klasik Mozart, kelompok kedua adalah kelompok yang diberi perlakuan musik tradisional gamelan jawa, dan kelompok ketiga sebagai kontrol tidak mendapat perlakuan. Tiap kelompok mendapat dua kali pengukuran nyeri dengan menggunakan numerical rating scale (NRS). Penilaian pertama (I) dilakukan pada saat ibu sudah berada pada fase aktif, yaitu sebelum diberi perlakuan, dan penilaian II pada akhir kala I persalinan setelah mendapat perlakuan mendengarkan musik. Musik yang diperdengarkan adalah CD relaksasi ibu dan bayi karya Mozart dan CD relaksasi gamelan jawa melalui tape portable player karena earphone dapat menambah ketidaknyamanan ibu yang sedang nyeri. Penelitian ini sudah mendapatkan persetujuan dari Komisi Etik Penelitian Kesehatan Fakultas Kedokteran Universitas Padjadjaran pada tanggal 12 November 2010.

\section{Hasil}

Pada Tabel 1 terlihat bahwa mayoritas ibu berusia 20-29 tahun yang berarti ibu berada pada usia reproduksi sehat. Pekerjaan ibu hampir seimbang 
Nike Sari: Perbandingan Efek Musik Klasik Mozart dan Musik Tradisional Gamelan Jawa terhadap Pengurangan Nyeri

Tabel 1 Distribusi Karakteristik Subjek Penelitian

\begin{tabular}{|c|c|c|c|c|}
\hline $\begin{array}{c}\text { Karakteristik } \\
\text { Subjek Penelitian }\end{array}$ & $\begin{array}{c}\text { Kelompok Musik } \\
\text { Mozart }\end{array}$ & $\begin{array}{c}\text { Kelompok } \\
\text { Musik Gamelan } \\
\text { Jawa }\end{array}$ & Kelompok Kontrol & Nilai $p$ \\
\hline Usia ibu (th) & 9 & 9 & 10 & $\mathbf{0 , 5 8 5}$ \\
\hline $20-29$ & 1 & 1 & 0 & \\
\hline$\geq 30$ & $25(4)$ & $25(4)$ & $25(3)$ & \\
\hline Rata-rata (SD) & & & & $\mathbf{0 , 0 3 6}$ \\
\hline \multicolumn{5}{|l|}{ Pekerjaan } \\
\hline Ibu rumah tangga & 8 & 1 & 5 & \\
\hline Swasta & 2 & 8 & 4 & \\
\hline PNS & 0 & 1 & 1 & \\
\hline Pendidikan terakhir & & & & 0,670 \\
\hline$\leq$ SLTA & 4 & 5 & 6 & \\
\hline$>$ SLTA & 6 & 5 & 4 & \\
\hline Suku asli & & & & 0,722 \\
\hline Jawa & 9 & 9 & 8 & \\
\hline Campuran Jawa & 1 & 1 & 8 & \\
\hline Luar Jawa & 0 & 0 & 1 & \\
\hline Kehamilan ke- & & & & 0,329 \\
\hline 1 & 10 & 8 & 9 & \\
\hline 2 & 0 & 2 & 1 & \\
\hline Usia kehamilan (minggu) & & & & 0,322 \\
\hline Rata-rata (SD) & $39,4(1,2)$ & $39,9(0,7)$ & $38,8(1)$ & \\
\hline $\begin{array}{l}\text { Pembukaan serviks }(\varnothing) \\
\text { datang }(\mathrm{cm})\end{array}$ & & & & 0,006 \\
\hline Median (rentang) & $2(1-7)$ & $2(1-8)$ & $2,5(1-8)$ & \\
\hline
\end{tabular}

Tabel 2 Karakteristik Nyeri Persalinan Kala I fase Aktif pada Dua Kali Penilaian pada Semua Kelompok

\begin{tabular}{lccc}
\hline $\begin{array}{c}\text { Nyeri Persalinan } \\
\text { Kala I Fase Aktif }\end{array}$ & Kelompok Musik Mozart & $\begin{array}{c}\text { Kelompok } \\
\text { Musik Gamelan Jawa }\end{array}$ & Kelompok Kontrol \\
\hline Penilaian I & 0 & 0 & 0 \\
Nyeri ringan (1-3) & 0 & 3 & 5 \\
Nyeri sedang (4-6) & 9 & 7 & 5 \\
Nyeri berat (7-9) & 1 & 0 & 0 \\
Nyeri hebat (10) & $7,5(7-10)$ & $7(5-9)$ & $7(4-9)$ \\
Median (rentang) & & & \\
Penilaian II & 0 & 0 & 0 \\
Nyeri ringan (1-3) & 6 & 3 & 1 \\
Nyeri sedang (4-6) & 4 & 6 & 4 \\
Nyeri berat (7-9) & 0 & 1 & 5 \\
Nyeri hebat (10) & $6(5-9)$ & $7,5(5-10)$ & $9,5(6-10)$ \\
Median (rentang) & & & \\
\hline
\end{tabular}

$\mathrm{SD}=$ Standar Deviasi 
Nike Sari: Perbandingan Efek Musik Klasik Mozart dan Musik Tradisional Gamelan Jawa terhadap Pengurangan Nyeri

Tabel 3 Hasil Statistik Perbandingan Nyeri Persalinan Kala I Fase Aktif pada Kelompok Mozart, Gamelan Jawa, dan Kontrol

\begin{tabular}{lcc}
\hline Intensitas Nyeri Persalinan Kala I Fase Aktif & ZW & Nilai p \\
\hline Kelompok Mozart & 2,401 & 0,016 \\
Kelompok gamelan jawa & 0,567 & 0,571 \\
Kelompok kontrol & 2,831 & 0,005 \\
\hline
\end{tabular}

antara ibu rumah tangga dan swasta, hanya dua orang yang bekerja sebagai pegawai negeri sipil. Pendidikan ibu juga seimbang antara $\leq$ SLTA dan >SLTA, sedangkan berdasarkan suku asli didapatkan mayoritas kehamilan pertama, hanya 3 (tiga) orang dengan kehamilan kedua, namun keseluruhannya ibu mengalami persalinan yang pertama dengan usia kehamilan aterm. Ibu datang pada pembukaan serviks dengan median 2 dan 3 pada masing-masing kelompok, yaitu pada kala I fase laten.

Terlihat pada tabel di atas perubahan nyeri sebelum dan sesudah perlakuan mendengarkan musik. Frekuensi nyeri sebelum perlakuan pada kelompok Mozart memiliki median 7,5 dengan rentang 7-10 menurun menjadi 6 (5-9). Berbeda dengan kelompok gamelan jawa yang sedikit mengalami peningkatan, dari median 7 (5-9) menjadi median 7,5 (5-10). Namun, peningkatan frekuensi nyeri pada kontrol jauh meningkat, yaitu dengan nilai median 7 (4-9) menjadi 9,5 (6-10). Untuk lebih jelas, nilai median pada penilaian I dan II pada ketiga kelompok diperlihatkan pada diagram yang ada pada Gambar di bawah ini.

Untuk mengetahui apakah terdapat perbedaan yang bermakna pada penggunaan musik klasik

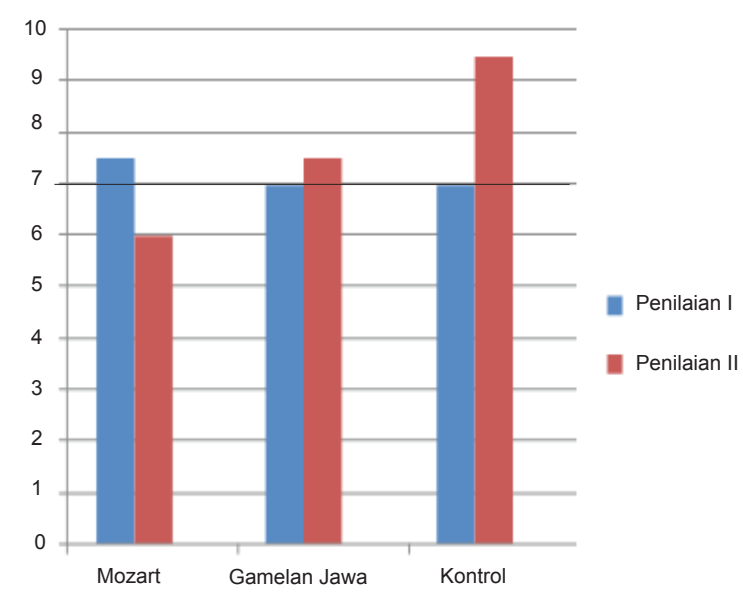

\section{Gambar Nilai Median pada Penilaian I dan} Penilaian II pada Semua Kelompok
Mozart, musik tradisional gamelan jawa, dan kontrol maka dilakukan analisis statistik dengan Uji Wilcoxon Signed Ranks (Z).

Berdasarkan analisis statistik ketiga kelompok dengan derajat kepercayaan $95 \%$, didapatkan perbedaan yang bermakna antara nyeri sebelum dan sesudah mendengarkan musik klasik Mozart $(\mathrm{p}=0,016$; Tabel 3). Kesimpulan kedua adalah terdapat perbedaan yang bermakna antara nyeri sebelum dan sesudah pada kelompok kontrol $(\mathrm{p}=0,005)$.

Pada penelitian ini tidak terdapat perbedaan bermakna antara musik klasik Mozart dan musik tradisional gamelan jawa pada pengurangan nyeri persalinankalaIfaseaktifpadanulipara.Perbedaan nyeri persalinan antara kelompok Mozart dan kelompok kontrol dengan Uji Mann Whitney untuk uji komparatif sampel berpasangan pada kedua kelompok tersebut bermakna $(\mathrm{p}=0,001$; Tabel 4). Hal ini menyimpulkan bahwa terdapat perbedaan nyeri persalinan pada penilaian kedua antara kelompok Mozart dan kelompok kontrol. Hasil uji komparatif perbedaan nyeri persalinan antara kelompok gamelan jawa dan kelompok kontrol, didapatkan $\mathrm{p}=0,022$ yang berarti terdapat perbedaan nyeri persalinan sesudah perlakuan antara kelompok gamelan jawa dan kontrol.

\section{Pembahasan}

Karakteristik ibu-ibu yang menjadi subjek pada penelitian ini dari segi usia didapatkan mayoritas 20-29 tahun. Usia termuda 20 tahun dan usia tertua 34 tahun. Berdasarkan usia tersebut, dapat disimpulkan bahwa semua ibu yang menjadi subjek penelitian berada pada usia reproduksi sehat, yaitu usia 20-35 tahun. Penelitian yang dilakukan Phumdoung dan Good ${ }^{10}$ di Thailand menggunakan musik untuk mengurangi sensasi dan tekanan nyeri persalinan dengan membatasi sampel nulipara berusia 20-30 tahun. Penelitian oleh Phumdoung dkk. ${ }^{11}$ yang juga di Thailand menggunakan kombinasi musik dan analgesik pada nyeri persalinan memiliki sampel primipara berusia 18-35 tahun.

Karakteristik berdasarkan pekerjaan bervariasi pada masing-masing kelompok. Pada kelompok 
Tabel 4 Hasil Statistik Perbedaan Nyeri Kala I Fase Aktif pada Semua Kelompok

\begin{tabular}{lcc}
\hline \multicolumn{1}{c}{ Intensitas Nyeri Persalinan Kala I Fase Aktif } & $\mathbf{Z}_{\mathbf{M}-\mathbf{w}}$ & Nilai $\mathbf{p}$ \\
\hline Kelompok Mozart dan gamelan jawa & 1,540 & 0,124 \\
Kelompok Mozart dan kontrol & 3,195 & 0,001 \\
Kelompok gamelan jawa dan kontrol & 2,286 & 0,022 \\
\hline
\end{tabular}

Mozart mayoritas bekerja sebagai ibu tumah tangga (80\%), pada kelompok gamelan jawa mayoritas swasta $(80 \%)$, sedangkan kelompok kontrol menunjukkan hampir seimbang antara ibu rumah tangga $(50 \%)$ dan swasta $(40 \%)$. Pendidikan yang dikelompokkan $\leq$ SLTA dan $>$ SLTA, pada tiap kelompok memiliki pembagian yang hampir merata. Penelitian Kimber dkk. ${ }^{12}$ di London menggunakan sampel nulipara dengan tingkat pendidikan sarjana dan di atas sarjana seimbang dengan $\leq$ level A (SLTA) pada masingmasing kelompok penelitiannya, sedangkan pada penelitian ini dilakukan di Yogyakarta, sehingga dapat diperkirakan sebelumnya mayoritas subjek penelitian adalah suku Jawa.

Subjek penelitian ini adalah nulipara yang berada pada kala I fase aktif, yaitu wanita yang belum pernah melahirkan sebelumnya dan yang sedang menghadapi proses persalinan untuk pertama kalinya. Dari data yang diperoleh hanya 3 orang yang merupakan kehamilan kedua yang mengalami abortus pada kehamilan pertamanya, tetapi tidak mengalami gangguan dan kelainan pada kehamilan sekarang. Ibu datang untuk bersalin memiliki usia kehamilan aterm 38-42 minggu. Usia kehamilan aterm (38-42 minggu) merupakan usia kehamilan yang terbaik untuk melahirkan. Diharapkan ibu beserta bayi yang akan dilahirkan berada pada kondisi fisiologis. Pembukaan serviks ibu ketika pertama kali datang ke RSIA Arvita Bunda, didapatkan nilai median 2 dengan rentang 1-7 pada kelompok Mozart, pada kelompok gamelan jawa didapatkan median 2 (1-8), dan 2,5 (1-8) pada kelompok kontrol.

Setelah proses persalinan pada semua subjek penelitian, didapatkan bayi dengan berat badan lahir (BBL) normal (2.500-4.000 g). Semua bayi lahir normal tanpa mengalami asfiksia, baik pada menit 1 maupun pada menit 5, yaitu dengan skor APGAR 7-10. Hal ini juga menandakan bahwa bayi yang dilahirkan sehat. Didukung oleh kriteria penelitian yang memiliki pembatasan kehamilan normal, outcome persalinan juga normal.

Nyeri persalinan subjek penelitian sebelum dan juga sesudah perlakuan mendengarkan musik mengalami penurunan. Frekuensi nyeri sebelum perlakuan pada kelompok Mozart memiliki nilai median 7,5 dengan rentang 7-10 mengalami penurunan menjadi median 6 (5-9). Kelompok gamelan jawa sedikit mengalami peningkatan nyeri, yaitu dari median 7 (5-9) menjadi rata-rata 7,5 (5-10). Sebagian ibu mengalami penurunan nyeri dan sebagian lain mengalami peningkatan, tetapi peningkatan pada kelompok ini tidak begitu besar dibandingkan dengan frekuensi nyeri pada kelompok kontrol jauh mengalami peningkatan dengan nilai median 7 (4-9) menjadi 9,5 (6-10). Kelompok kontrol tidak mendapat perlakuan diperdengarkan musik, baik musik klasik Mozart maupun musik tradisional gamelan jawa. Hal ini menandakan bahwa pada persalinan normal secara fisiologis ibu akan mengalami nyeri yang semakin lama semakin kuat seiring dengan penambahan pembukaan serviks. Tidak jarang ibu yang di akhir kala I persalinan akan berada pada skala nyeri berat atau hebat.

Menurut Sherwen dkk. dikutip oleh Yuliatun ${ }^{4}$ dinyatakan bahwa primipara akan mengalami intensitas nyeri persalinan lebih berat daripada multipara, terutama pada kala I persalinan karena effacement biasanya terjadi lebih dulu daripada dilatasi serviks. Di samping itu pada primipara, proses persalinan yang dihadapinya adalah yang pertama kali sehingga belum ada pengalaman sebelumnya yang dapat menyebabkan ketegangan emosi, cemas, dan juga takut yang tentunya dapat memperberat persepsi nyeri tersebut. Menurut Gatson-Johansson dkk. yang dikutip Bachman, ${ }^{3}$ proses persalinan pada primipara lebih lama daripada multipara sehingga menimbulkan lelah yang berpengaruh pada peningkatan persepsi nyeri. Keadaan ini terlihat pada kelompok kontrol dengan intensitas nyeri yang meningkat pada akhir fase aktif persalinan.

Untuk membandingkan keadaan nyeri yang dialami oleh ibu pada ketiga kelompok dilakukan analisis uji komparatif dengan Uji Wilcoxon Signed Ranks $(\mathrm{Z})$ dan derajat kepercayaan 95\%. Didapatkan hasil $\mathrm{p}=0,016$ pada kelompok Mozart yang berarti bahwa terdapat perbedaan bermakna antara nyeri sebelum dan sesudah mendengarkan musik klasik Mozart. Keadaan ini terjadi oleh karena intensitas nyeri pada kelompok Mozart mengalami penurunan, sedangkan pada kelompok gamelan jawa $(p=0,571)$, berarti tidak terdapat perbedaan yang bermakna antara nyeri sebelum 
dan sesudah mendengarkan musik tradisional gamelan jawa. Kesimpulan ini didapatkan karena intensitas nyeri pada kelompok gamelan jawa ada yang mengalami penurunan, tetapi ada juga yang mengalami peningkatan. Pada kelompok kontrol didapatkan $\mathrm{p}=0,005$, hal ini menjelaskan bahwa terdapat perbedaan yang bermakna antara nyeri sebelum dan sesudah pada kelompok kontrol. Hal ini terjadi karena pada kelompok kontrol terjadi peningkatan intensitas nyeri pada semua subjek penelitian.

Untuk mengetahui perbedaan intensitas nyeri antara kelompok Mozart, gamelan jawa, dan kontrol, dilakukan uji komparatif dengan analisis statistik Kruskal Wallis menurut Sugiyono. ${ }^{13}$ Berdasarkan Uji Mann Whitney antara kelompok Mozart dan kontrol didapatkan hasil $\mathrm{p}=0,001$; berarti terdapat perbedaan nyeri persalinan setelah mendengarkan musik klasik Mozart dibandingkan dengan kelompok kontrol. Kesimpulan tersebut sesuai dengan penelitian yang dilakukan oleh Phumdoung dan Good ${ }^{10}$ dengan menggunakan musik selama tiga jam, didapatkan skor nyeri satu jam pertama menurun menjadi 95\%, 89\% pada jam kedua, dan 73\% pada jam ketiga.

Penelitian yang dilakukan Phumdoung serta Good ${ }^{10}$ menggunakan musik yang dipilih ibu dari beberapa tipe musik relaksasi yang sebelumnya telah diperdengarkan selama 30 menit. Musik yang disediakan adalah musik yang di dalamnya mengandung alunan harpa, piano, orkestra, dan jazz, dengan ketukan 60-80 per menit. Pilihan musik yang dipergunakan untuk mengurangi nyeri persalinan sama dari segi ketukan yang lambat, instrumental yang ada, perbedaannya tidak difokuskan pada musik yang sama. ${ }^{14}$ Pada dasarnya musik tersebut memiliki karakteristik yang serupa musik klasik Mozart. Phumdoung dan Good ${ }^{10}$ mempergunakan earphone pada penelitiannya. Pada penelitian ini, musik yang diperdengarkan melalui portable tape player seperti halnya penelitian yang dilakukan oleh Tabarro dkk. ${ }^{15}$ di Brazil. Dalam penelitiannya Tabarro dkk. ${ }^{15}$ juga menggunakan musik yang mengalun lembut yang direkomendasikan oleh ibu yang menjadi sampel. Musik yang digunakan antara lain musik barok (Bach, Vivaldi), klasik (Mozart), musik romantis, dan kontemporer.

Otak berperan mengubah kondisi fisik tubuh dalam responsnya terhadap musik. Pada musik relaksasi, ritme musik dapat memandu tubuh menjadi bernapas lebih lambat dan mendalam, sehingga dapat memberikan efek menenangkan. Detak jantung dan tekanan darah juga dapat merespon musik yang didengarkan. Efek mental juga bergantung pada tipe serta jenis musik, musik dapat mengasah ketajaman mental atau membantu dalam relaksasi. Efek musik terhadap emosional dapat memengaruhi suasana kejiwaan manusia menjadi lebih baik dan lebih lanjut dapat membuat tubuh bergerak. Bervariasinya musik secara kejiwaan memungkinkan dipergunakan untuk menciptakan perasaan yang menenangkan. Efek musik seperti yang telah dijelaskan di atas membuat ibu yang sedang dalam kala I fase aktif persalinan dapat menikmati musiknya jika musik tersebut tepat. Pada nyeri kronik dan akut, suasana kejiwaan dan emosional penderita memberikan pengaruh yang kuat pada persepsi nyeri yang dihasilkan dan kemampuan untuk mengatasinya. Musik Mozart yang dipergunakan adalah musik ciptaan oleh Wolfgang Amadeus Mozart dalam bentuk compact disc (CD) edisi khusus relaksasi untuk ibu dan bayi. Mendengarkan musik yang menenangkan dengan rangsangan irama yang tepat memungkinkan tubuh untuk menghasilkan endorphine yang terbentuk secara alami dalam mengurangi nyeri. ${ }^{14,15}$

Uji komparatif perbedaan nyeri persalinan dengan perlakuan kelompok musik tradisional gamelan jawa dan kontrol didapatkan $\mathrm{p}=0,022$; yang berarti terdapat perbedaan bermakna nyeri persalinan antara kelompok yang mendengarkan musik tradisional gamelan jawa dan kelompok kontrol. Musik yang dihasilkan oleh 40-60 jenis alat musik ini dinyatakan sebagai musik yang dihasilkan oleh kreativitas budaya yang tinggi karena keanekaragaman alat, irama, dan nada yang dihasilkan. ${ }^{16}$ Menurut Lee dalam artikelnya Loth, ${ }^{8}$ ternyata kolaborasi berbagai instrumen yang berbeda pada gamelan jawa memberikan struktur tersendiri yang baik untuk improvisasi dalam musik terapi.

Kivy yang dikutip oleh Salim ${ }^{9}$ menyatakan, ekpsresi musik sangat terkait dengan "emosi budaya" seperti gerak, cara bicara, dan sikap tubuh. Karena "emosi budaya" berbeda, maka hubungan antara berbagai rangsangan elemen musik tertentu yang dihasilkan juga berbeda. Suku Jawa merupakan suku yang ada di Indonesia yang terkenal dengan pembawaan masyarakatnya yang tenang dan sikap santun yang tinggi. Karawitan jawa menonjolkan kestabilan mental pemain musik beserta pendengarnya, keindahan terletak pada suara musik yang tidak hingar bingar tetapi enak didengar serta keteraturan irama..$^{9,16}$

Seorang musisi yang juga seorang psikolog bernama Salim, telah melakukan penelitian di Yogyakarta mengenai pengaruh elemen tempo dan juga timbre gamelan jawa terhadap respons emosi musikal pendengarnya. Penelitian tersebut menunjukkan hasil yang signifikan, baik pada kelompok musisi maupun nonmusisi. Penelitian ini juga dilaksanakan di Kota Yogyakarta yang tentunya mayoritas masyarakat adalah suku Jawa. Dari data yang didapatkan, subjek penelitian ini 
pada kelompok gamelan jawa $90 \%$ adalah suku Jawa dan $10 \%$ suku campuran Jawa. Terdapat hubungan ekspresi musik dengan emosi budaya sesuai dengan pernyataan Kivy di atas, didukung oleh hasil yang didapatkan pada penelitian ini. Ibu yang bersuku Jawa dengan kebiasaan tradisi jawa yang sudah mengental dalam kehidupannya seperti ekspresi gerak, cara bicara, dan sikap tubuh tentunya merasa tersambung dengan musik gamelan yang sudah biasa didengarkan. Tubuh ibu langsung menyatu dengan musik gamelan jawa seiring dengan alunannya yang didengarkan selama fase aktif persalinan. ${ }^{9}$

Saleh ${ }^{16}$ seorang dokter spesialis saraf menulis buku yang berisikan kehidupan manusia Jawa dilihat dari perspektif ilmu kedokteran modern. Dia menjelaskan bagaimana kebudayaan jawa mampu menyumbangkan suatu hal penting bagi dunia kesehatan. Menurut Saleh, ${ }^{16}$ orang Jawa yang kebetulan menderita strok yang biasanya dilatarbelakangi hipertensi bila mendengarkan gamelan jawa dan tarian jawa dalam durasi lama akan terpengaruh secara psikis menjadi tenang, tidak ada gejolak mental yang mendadak. Saleh juga telah menyatakan bahwa pendekatan emosi budaya dapat sangat berpengaruh pada pasien.

Suhartini ${ }^{17}$ telah menggunakan terapi musik gamelan jawa pada pasien penyakit jantung di RS Karyadi Semarang. Dari penelitian tersebut disimpulkan bahwa, musik gamelan jawa dapat dijadikan sebagai musik terapi untuk mengurangi kecemasan, sensasi nyeri, dan beberapa efek yang sangat memengaruhi psikologis. Dinyatakan juga bahwa musik gamelan jawa dapat dipergunakan sebagai musik terapi. Musik gamelan dapat dijadikan sebagai musik terapi pada pasien yang mengalami nyeri akibat proses persalinan, terbukti dengan $p=0,22$ pada hasil perbedaan nyeri antara kelompok gamelan jawa dan kelompok kontrol. Artinya ada perbedaan nyeri persalinan setelah mendengarkan musik tradisional gamelan jawa dibandingkan dengan kelompok kontrol yang tidak mendengarkan musik.

Linton $^{18}$ dalam artikelnya menyatakan musik dapat melakukan apapun. Sebuah lagu dapat berkoordinasi dengan tubuh saat proses persalinan. Musik yang didengarkan secara intensif dapat memberikan kekuatan penuh, dalam arti untuk merefleksikan emosi diri, penerangan jiwa, dan ekspresi. Satu hal yang terpenting bahwa musik tidak dapat membuat segalanya menjadi lebih baik. Lebih lanjut Linton menyatakan, faktanya musik dengan cepat menarik pendengarnya dan pendengar memilih musik karena dia menemukan resonansi musik tersebut dengan dirinya sesuai dengan kondisi emosi, tetapi musik itu sendiri tidak pernah menyebabkan pendengarnya untuk bertindak. Intinya bahwa musik dapat membantu seseorang jika orang tersebut menginginkannya. Ibu yang dalam proses persalinan dapat terbantu untuk mengatasi nyeri yang dialaminya apabila ibu tersebut memang menginginkannya. Keadaan ini terbukti pada ibu yang telah mendengarkan musik Mozart maupun gamelan jawa mengalami peningkatan intensitas nyeri sama seperti ibu dalam kelompok kontrol.

Secara statistik tidak terdapat perbedaan yang bermakna antara musik klasik Mozart dan musik tradisional gamelan jawa terhadap pengurangan nyeri persalinan kala I fase aktif pada nulipara $(p=0,124)$. Hal ini berarti bahwa musik tradisional gamelan jawa dapat dipergunakan sebagai musik alternatif untuk mengurangi nyeri persalinan ibu pada kala I fase aktif. Karena penelitian ini subjeknya adalah suku mayoritas Jawa, tentunya secara budaya memiliki hubungan emosi yang erat dengan musik gamelan jawa dengan demikan musik gamelan jawa akan lebih efektif untuk mengurangi nyeri persalinan kala I fase aktif ibu suku Jawa.

Teori gate control menjelaskan bagaimana musik dapat menurunkan nyeri dalam persalinan. Perjalanan impuls nyeri dan juga mendengarkan musik berada pada spinal tertutup dengan musik terapi. Antara impuls nyeri dan mendengarkan musik yang disalurkan ke otak akan mengalami kompetisi selama perjalanan menuju otak dan impuls mendengarkan musik akan dipersepsikan terlebih dahulu oleh otak daripada impuls nyeri. Dalam hal ini terapi mendengarkan musik dapat menyebabkan tubuh mengalami kekacauan untuk mempersepsikannya. Ketika musik didengarkan untuk mengatasi nyeri, maka akan berkurang kecemasan dan ketenangan pada ibu, tubuh akan mengalami kekacauan dalam mempersepsikan yang akhirnya berfokus pada penurunan nyeri akibat kontraksi. Penggunaan musik tidak dapat menghilangkan nyeri secara keseluruhan, tetapi musik dapat mengatasi ketidaknyamanan selama persalinan. ${ }^{4}$

Simpulan, musik klasik Mozart dan musik tradisional gamelan jawa dapat mengurangi nyeri persalinan kala I fase aktif pada nulipara, dan tidak ada perbedaan antara musik klasik Mozart dan musik tradisional gamelan jawa dalam mengurangi nyeri persalinan kala I fase aktif pada nulipara. Musik tradisional gamelan jawa lebih efektif digunakan pada nulipara suku Jawa dalam mengurangi nyeri persalinan kala I fase aktif yang dialaminya.

Disarankan musik klasik Mozart dan musik tradisional gamelan jawa dipergunakan sebagai media untuk mengurangi nyeri yang dirasakan ibu waktu proses persalinan di Indonesia. Sebaiknya ada penelitian lanjutan mengenai jenis musik lain yang dapat digunakan untuk mengurangi nyeri 
persalinan, terutama musik tradisional Indonesia yang memiliki kemiripan irama dengan musik tradisional gamelan jawa.

\section{Daftar Pustaka}

1. Tournare M, Theau A. Complementary and alternative approaches to pain relief during labor. J Obgyn. 2007;4(4):409-17.

2. Lowdermilk DL. Faktor esensial dan proses persalinan. Dalam: Bobak IM, Lowdermik DL, Jensen MD, Perry SE, penyunting. Keperawatan maternitas. Edisi ke-4. Jakarta: EGC; 2005. hlm. 234-48.

3. Bachman JA. Penatalaksanaan rasa tidak nyaman. Dalam: Bobak IM, Lowdermik DL, Jensen MD, Perry SE, penyunting. Keperawatan maternitas. Edisi ke-4. Jakarta: EGC; 2005. hlm. 252-72.

4. Yuliatun L. Penanganan nyeri persalinan dengan metode nonfarmakologi. Malang: Bayumedia Publishing; 2008.

5. Campbell D. Efek Mozart memanfaatkan kekuatan musik untuk mempertajam pikiran, meningkatkan kreativitas, dan menyehatkan tubuh. Jakarta: PT Gramedia Pustaka Utama; 2002.

6. Bassano M. Terapi musik dan warna. Yogyakarta: Rumpun; 2009.

7. Mucci K, Mucci R. The healing sound of music (manfaat musik untuk kesembuhan, kesehatan, dan kebahagiaan anda). Jakarta: Gramedia Pustaka Utama; 2002.

8. Loth H. How gamelan music has influenced me as a music therapist-a personal account.
Voices. 2006;6(1) [diunduh 6 Agustus 2010]. Tersedia dari: http://www.voices.no

9. Salim D. Respons emosi musikal dalam gamelan jawa. Psikologia. 2005;1(2):63-73.

10. Phumdoung S, Good M. Music reduce sensation and distress of labor pain. Pain Management Nursing. 2003;4(2):54-61.

11. Phumdoung $\mathrm{S}$, Bhitakburapab A, Chanaudom B, Ajasareyasing T, Petcharat T. Effects of the combination of small dose analgesic and music on labor pain. Songkla Med J. 2007;25(2):99-105.

12. Kimber L, McNabb M, Mc Court C, Haines A, Brocklehurst P. Massage or music for pain relief in labour: a pilot randomized placebo controlled trial. Eur J Pain. 2008;12:961-9.

13. Sugiyono. Statistika untuk penelitian. Bandung: Alfabeta; 2009.

14. Gale Encyclopedia of Medicine. Music therapy [article online]. American Music Therapy Association; 2011 [diunduh 3 Mei 2011]. Tersedia dari: http://www.gale. cengage.com

15. Tabarro CS, Campos LB, Galli NO, Novo NF. Effect of the music in labor and newborn. Rev Esc Enferm USP. 2010;44(2):441-8.

16. Saleh AY. Rahasia otak manusia Jawa. Yogyakarta: Pinus; 2010.

17. Suhartini. Music and music intervention for therapeutic purpose in patients with ventilator support: gamelan music perspective. Nurse Med J Nursing. 2011;1(1):129-46.

18. Linton M. The Mozart effect. Univ Forum [article oline]. 1999 [diunduh 14 April 2011]. Tersedia dari: http://www.univforum.org 